CANADA

\section{Rethinking nuclear policy}

A contribution to Canada's nuclear debate has come from the head of the Science Council of Canada. David Spurgeon reports from Ottawa

THE executive director of the Science Council of Canada, John J. Shepherd, has called for the federal government to set up a concentrated, focused, nuclear industrial strategy. The call, his most recent public pronouncement, indicates how much he has done to shape a new, bolder, more public and more independent role for the Council, something it has sought over this past concluding year to its first decade.

Shepherd came to the council from industry, where he was chairman of a successful high technology instrument firm, and he brought with him the vigorous, pragmatic approach one would expect from such a background. So his public statements tend to be hard-hitting and to the point. This latest, which was contained in an article in The Financial Post, was no different.

Shepherd acknowledged that there are serious matters still to be resolved regarding the nuclear power issue in Canada-like other industrialised countries, Canada has become locked in debate over questions like the safety and security of reactors and the disposal of radioactive waste. But it stated that nuclear power in Canada "is a fact -and it would be foolish not to take advantage of the opportunities it offers." And it went on to point out that the size of the proposed nuclear power programme in Canada in future is very large: an estimate of 70 nuclear power units by the end of the century is decidedly conservative, which means the market will be an average of $\$ 1,500$ million a year for the next 25 years.

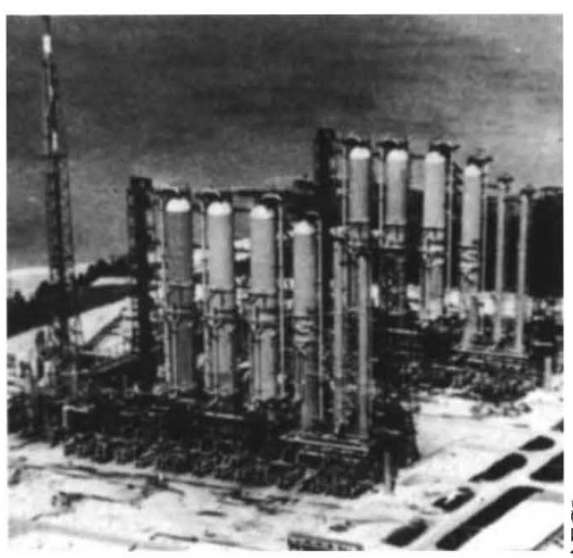

Bruce heavy water plant, Ontario
This means, said Shepherd, that "it is imperative that we devote a good deal of attention to planning." Three sectors are involved in the Canadian nuclear programme: Atomic Energy of Canada Ltd (AECL), a Crown corporation that carries out research, development and engineering; the provincial electrical utilities, which operate the plants; and industry, which does the manufacturing. "It is painfully clear," said Shepherd, "that industry has so far been unable to carry its weight in this arrangement."

This comment was nothing new: as far back as the 1960s, AECL officials were saying the same thing. But Shepherd went on to say that industry's contribution has been rendered in effective by cancellations or postponements in nuclear plant construction, lack of a steady stream of nuclear projects, low-volume ordering and low profit margins. Those wanting to break into the market, particularly in some of the specialised instrumentation areas, were frustrated by piecemeal orders. What is required, he added, is a "mixed nuclear consortium-comprising electrical utilities, AECL, and industry", and for this to happen, several changes would have to be made.

Electrical utilities would have to alter their construction philosophies and permit others to play a greater coordinating role. AECL would have to hand over to the new consortium its Power Projects group, which carries out its engineering functions. And industry would have to accept new responsibilities. If AECL's heavy water production activities were also transferred to such a consortium, it would leave only its original research and development function. Under another name this could become the institutional focal point for a major thrust in energy research development, "for cxample, along the lines of the US Energy Research and Development Administration. Such an expansion of responsibilities might also contribute to the initiation of a national energy policy."

Shepherd again made it clear he thought the domestic market for nuclear power station more important to Canada than foreign ones, and referred to losses associated with a nuclear sale to Argentina. Others have pointed to difficulties Canada has had with sales to countries like South Korea, India and Pakistan. If Canadian industry could not grasp the opportunities presented by the domestic nuclear market, "it should not complain when government fills the vacuum."

\section{IN BRIEF \\ Nobel prizes announced}

The $\$ 160,000$ Nobel prize for medicine will be shared by Professors Baruch Blumberg and Carleton Gajdusek. Dr Blumberg is professor of Medical Genetics at the Institute for Cancer Research of the University of Pennsylvania and Dr Gajdusek works at the National Institutes of Health, Bethesda; both men did their prize-winning work at the National Institutes of Health. Both prizes are for research in virology, Professor Blumberg's for discovering Australia Antigen, a particle associated with serum hepatitis (hepatitis B), and Professor Gajdusek's for the fundamental research on kuru, the slow virus disease that was prevalent in the cannibalistic Fore tribe of New Guinea.

The prize for physics goes to Professor Burton Richter of Stanford and Samuel Ting of MIT for their work on the $\mathrm{J} / \psi$ particle. The particle, discovered simultaneously and independently by the two researchers in 1974 , has opened up new realms of investigation with the new property of matter known as 'charm'.

The prize for chemistry is awarded to Professor William Lipscomb of Harvard for his work on boranes. The bonding of these compounds was long a puzzle according to conventional valency ideas; Lipscomb in the 1950s took the new multicentred-bonding theory, predicted borane structures and used elegant X-ray crystallography to show that some of these structures were actually cages, one even an icosahedron.

\section{2,4,5-T production ended}

Britain's only producer of 2,4,5 trichlorophenol, the chemical being manufactured at Seveso when the poison TCDD was accidentally released, has decided not to recommence production. The company, Coalite and Chemical Products Ltd, of Bolsover, Derbyshire, stopped production in August "to make $110 \%$ sure" of its safety measures. Coalite had operated with more stringent safety measures than the Italian plant, but after the Seveso accident UK Health and Safety inspectors recommended even more precautions. The company has blamed over-sensational publicity of the Seveso accident for its decision.

- A list of 721 highly poisonous substances has been prepared by the Ministry for the Environment of the West German State of North Rhine Westphalia. Included are all chemicals with an effect similar to that of TCDD, some even more poisonous and some less poisonous but still potentially lethal. 